\title{
Flood Risk Pattern Recognition Using Chemometric Techniques Approach in Golok River, Kelantan
}

\author{
Wan Nur Amyliyana Wan Faizurie Zaidee ${ }^{1}$, Ahmad Shakir Mohd Saudi ${ }^{1 *}$, Mohd Khairul Amri Kamarudin ${ }^{2}$, Mohd \\ Ekhwan Toriman ${ }^{3}$, Hafizan Juahir ${ }^{2}$, Izuddin Fahmy Abu ${ }^{1}$, Muaz Mahmud Nur Zahidah Shafii ${ }^{1}$, Khairul Nizam $^{4}$, \\ Rahmah Elfithri ${ }^{5}$ \\ ${ }^{I}$ Department of Environmental Health, Institute of Medical Science Technology Universiti Kuala Lumpur, Kajang, Selangor, Malaysia \\ ${ }^{2}$ East Coast Environmental Research Institute (ESERI), Universiti Sultan Zainal Abidin, Gong Badak Campus, 21300 Kuala Nerus, Ma- \\ laysia \\ ${ }^{3}$ Faculty of Social Sciences and Humanities, Universiti Kebangsaan Malaysia, 43600 Bangi, Selangor, Malaysia \\ ${ }^{4}$ Department of Civil and Structural Engineering, Faculty of Engineering and Built Environment, Universiti Kebangsaan Malaysia, \\ 43600 Bangi, Selangor, Malaysia \\ ${ }^{5}$ Institute for Environment and Development (LESTARI), Universiti Kebangsaan Malaysia, 43600 Bangi, Selangor, Malaysia \\ *Corresponding authorE-mail: ahmadshakir@unikl.edu.my
}

\begin{abstract}
This study was implemented to evaluate the flood risk pattern recognition in Golok River, Kelantan. Based on Spearman correlation test, it showed that water level and suspended solid was very strong and significant $(\mathrm{p}<0.0001)$. There was also a weak correlation of coefficient of stream flow and rainfall with the changes of water level as the p-value close to 1 . Suspended solid has strong corresponded in changing the rate of water level, as it described the rate of surface run-off that flowed into the water body. However, the risk of flood in study area is irrelevant to the monsoon season. Principle Component Analysis (PCA), the most sensitive parameters that contribute to the flood occurrence were identified with variability $\mathrm{R}^{2}$ value of 0.812 and 0.764 . Expansion and development by human activities contribute to the incline of stream flow and suspended solid in Golok River. Based on Statistical Process Control (SPC), water level of all parameters exceeded the Upper Control Limit (UCL), considered as high risk and vulnerable for flood and it is mostly due to man-made activities. It was not deniable that monsoon season played role in contributing flood occurrence as parameters of rainfall and water level have moderately positive factor loading.
\end{abstract}

Keywords: Chemo metric Techniques; Flood; Human Activities; Monsoon Season; Water Level.

\section{Introduction}

Flood is commonly acknowledged as natural disaster that happen all around the world and this phenomenon are seen to be extremely complex. Government or society tried to minimalize or totally control this unwanted condition. According to Department of Irrigation and Drainage (DID), flood is defined as overflowing of water from the bank of a stream, lake or drainage system onto adjacent land resulting from storm, ice melt, tidal action and channel obstruction [1].

Flooding is one of the biggest natural disasters which threaten lives, spreads infectious disease and brings damage to the property. $40 \%$ to $50 \%$ of death in the world is caused by flooding events [2]. Flood is not only occurred at certain area as this phenomenon is also rapid and extensive.

In Malaysia, with the average annual rainfall of $2,400 \mathrm{~mm}$ for Peninsular Malaysia and 2,600 - 3,2800 mm for Sabah and Sarawak, the most intense flood disaster is often occurred during monsoon season. There are two types of monsoon season, Northeast Monsoon that occurred between November to March and Southwest Monsoon that happened between May to September. Malaysia received heavy rainfall between November to March every year as reported by Malaysia Meteorology Department (MMD)
[3]. During this period, it is expected to face enormous flood hit the area that located mostly at east coast region such as Kelantan, Terengganu, Pahang and east part of Johor. The massive flood not only solely affected economy, but also engaged the agricultural sector.

Kelantan is one of badly effected zone by gigantic flood disaster. It is an annual occurrence disaster of varying severities in Kelantan state. Flood disaster was the most significant and largest chronicled flood in the history of Kelantan considering it to be a "tsunami-like disaster" which commonly called as "Bah Kuning" due to its high content of mud [4]. Therefore, higher content of mud will affect to the lower conductivity which decreased the concentration of salt minerals that important for agricultural sector and it was also another contributing factor in the increasing of suspended solids and also decreases in dissolved oxygen which will leads to the damage of the river ecosystem [5].

Most people lives in this state suffered from damages of properties, crops, livestock and vehicles. There were also several infrastructures such as buildings, schools, hospitals, railways and bridges were utterly bushed [4-7].

This state also is dipped with the yellowed-colored water during the flood events. Main rivers in Kelantan state such as Kuala Krai, Manek Urai, Gua Musang and Jeli, which are the affected districts, not only exposed to the destruction of man-made infrastruc- 
ture and residential area, but they also experienced landslide at numerous scale [8].

Flood disaster is a concerning issue towards people in this millennia as more people tend to face the strong impact and consequences the ambient of demography due to the worst flood events.

\section{Material and Methods}

\subsection{Topography of Sg. Golok}

Sg. Golok that located in Rantau Panjang, attained the highest water level which at 10.84 meters. This level was being considered as beyond the danger level of 9 meters [4].

Study by [6] recorded that the population of Sg. Golok area in 2005 is 38 thousand of people. Other than fishing and livestock farming, they are much more likely exposed to retail business, safety, tourism, transportation and infrastructure.

\subsection{Physical Phenomenon}

In [10] remark that flood activity caused by terrigenous material that have composed becomes flood deposits, mobilized during intense precipitation in the catchment area and eventually deposited at the bottom of lake. Weather factors that include heavy or continuous precipitation, snowmelts or storm surge from cyclones that generate high winds were said to be one of the physical phenomenon that leads to flood risk occurrence.

Flood also were claimed by [12] that it took place when a river bursts its banks, which it was more likely to happen with the contribution of heavy rains [11]. Continuously heavy rainfall might cause floods with sudden rise of the water level together with significant peak discharge lead to overflow of water for several durations of several days at certain locations. Under these conditions, it would also reduce the river's ability to supply fresh water for human activities and the river's capacity to support any aquatic life or recreational uses will be nearly zero and lastly would cause severe damage to the river ecosystem.

\subsection{Man-Made Activities}

The severity of flood events was not solely allied to the intensity of the natural hazard, but also too many human-driven factors which arising the flood risk. In [13] claimed that growing population and continual development in flood-prone areas are expected to increase the risk of flood to happen.

This study is also supported by another study which stated that as the population is growing up, the greater per capita usage of water in order to live in a better quality of life, urbanization and industrialization [14].

Furthermore, a study stated that public facilities, infrastructure, residential, commercial and the surrounding agricultural activities are not properly zoned thus become factors that contributed to the flood events [6]. Flooding problem can be associated with the loss of flood storage resulting the development extending and took over flood plain and drainage corridors, increased of runoff rates which due to the highly urbanization, inadequate drainage system, constriction at bridges that were either blocked by debris build-up or from other causes and siltation in waterways cannels as well as inadequate river capacity [15].

An analysis revealed that human development caused elevated rate in the surface run-off which affected the water level and the stream flow [16]. Along with the advancement of the country, human factors become the priority in contributing to the occurrence of flooding in a place. It is undeniable since most of the researchers have already annotations on these issues.

\subsection{Chemo metric Techniques}

In environmental fields, data analysis using Chemometric techniques has gained credibility and widely used [17]. Moreover, in [16] stressed that this method was useful in comparing variables of hydrological data that gave highest effect towards the changes of water level.

In order to expand the empire of research work in environmental field nowadays, most of the researchers including local researchers are highlighting this technique. It is advantageous to all parties that either directly or indirectly involved determining the pattern of natural risk which it is not only flood event.

\subsection{Experimental}

Golok River monitoring station is used in this study as the sampling station. Golok River is a stream at the fringe that different Malaysia (Kelantan) with Thailand (Narathiwat) with area 7.915 mi2 with the coordinate of latitude: $6^{\circ} 01^{\prime} 51^{\prime \prime} \mathrm{N}$; longitude: $101^{\circ}$ 95 ' 19" E, which summons a catchment range of 2,175 sq. km. The basin has an annual rainfall of about 2,500 $\mathrm{mm}$ which occurs during monsoon on October until January.

Secondary flood data are derived from Hydrology Department of DID. This study used secondary data from 1996-2016 which include four parameters; water level, stream flow, suspended solid and rainfall to determine the flood risk pattern. The measurement of these variables is recorded for 24 hours each day.

\subsection{Data Analysis}

Data are analyzed by using XLSTAT Base 2016 add-in software. If the computed $\mathrm{p}$-value is lower than the significance level alpha $=0.05$ and the $\mathrm{p}$-value $<0.0001, \mathrm{H}_{0}$ should be rejected and alternative hypothesis must be taken. This test needs to be done when the competed dataset without missing value is attained. Thus, data treatment was done to this dataset to predict the unknown value; the principle of nearest neighboring method was exerted by referring to the known value of nearest neighboring location. To estimate the missing values, the endpoint of the gaps was used. Below showed the equation used in this process [18]:

$$
y=y_{1} \text { if } x \leq x_{1}+\left[\frac{x_{2}-x_{1}}{2}\right] \text { or } y=y_{2} \text { if } x>x_{1}+\left[\frac{x_{2}-x_{1}}{2}\right]
$$

Definition 2.1: Where ' $y$ ' represents the interpolate, ' $x$ ' is the time point of the interpolate, ' $y_{1}$ ' and ' $x_{1}$ ' are the coordinates of the starting point of the gap and ' $y_{2}$ ' and ' $x_{2}$ ' are the end points of the gaps.

\subsection{Principal Component Analysis (PCA)}

PCA is applied in this study to outline a large number of variables into smaller sets. This method works by comparing sets of data and identifies the variables that affect the most towards the change of water level in the study area [16]

In this study, interrelated variables will be interpreted by PCA to identify the parameter that contributes to the flood occurrence. This method will visualize the most and less significant parameters without losing much information [16]. PCA can be implemented by calculated as in Equation (2):

$$
z_{i j}=\alpha_{i 1} x_{j 1}+\alpha_{i 2} x_{j 2}+\alpha_{i 3} x_{j 3}+\cdots+\alpha_{i m} x_{j m}
$$

Definition 2.2: Where ' $z$ ' is component score, ' $\alpha$ ' is component loading, ' $x$ ' is the measured value of variables, ' $i$ ' is the component number, ' $j$ ' is the sample number and ' $m$ ' is the total number of variables. 


\subsection{Statistical Process Control (SPC)}

SPC is used to predict the water level at the study area. In predicting hydrological modeling, Saudi et al. stressed that there are three important result were important, and those result were upper control limit (UCL), average value (AVG) and lower control limit (LCL) where the sigma in the control chart is represented within the value range of a set of data [16].

The control can uncover some trends and patterns showing how the actual data deviations from the historical baseline, displaying the best base lining and dynamic threshold as well as being able to capture unusual resource usage [19]. This analysis used is in Equation (3):

$$
\overline{\mathrm{x}}=\frac{\sum_{\mathrm{i}=1}^{\mathrm{m}} \mathrm{x}_{\mathrm{i}}}{\mathrm{m}}
$$

Definition 2.3: Where ' $\bar{x}$ ' is moving range, ' $m$ ' is individual value and ' $x_{i}$ ' is diferrence between data point.

\section{Results and Discussion}

\subsection{Analyzing the Relationship between Selected Varia- bles That Contribute to the Flood Occurrence}

The rates of correlation between variables studied were explained based on p-values. According to study by [20] in correlation test the relationship between variables was considered to be strong and significant when the p-value was less than 0.05.

Correlation of coefficient analysis result for selected variables based on p-value $<0.0001$ was presented in the Table 1 below where it showed that water level and suspended solid was very strong and significant. In a meantime, there was also a correlation between rainfall and suspended solid recorded according to the table of result below. Meanwhile, the result for stream flow and rainfall showed weak correlation of coefficient with other variables as their p-value close to 1 .

Table 1: Correlation of Coefficient Test for Selected Variables Based on P-value

\begin{tabular}{|c|c|c|c|c|}
\hline & $\begin{array}{c}\text { Water } \\
\text { Level } \\
(\mathrm{m})\end{array}$ & $\begin{array}{c}\text { Stream } \\
\text { Flow } \\
\left(\mathrm{m}^{3} / \mathrm{s}\right)\end{array}$ & $\begin{array}{c}\text { Rainfall } \\
(\mathrm{mm})\end{array}$ & $\begin{array}{c}\text { Suspended } \\
\text { Solid } \\
(\mathrm{mg} / 100)\end{array}$ \\
\hline Water Level & 1 & 1.000 & 1.000 & $<0.0001$ \\
Stream Flow & 1.000 & 1 & 1.000 & 1.000 \\
Rainfall & 1.000 & 1.000 & 1 & 0.000 \\
Suspended Solid & $<0.0001$ & 1.000 & 0.000 & 1 \\
\hline
\end{tabular}

It was clear that suspended solid has strong corresponds in changing the rate of water level at the study area as it described the rate of surface run-off that flowed into the water body. Thus, the risk of flood in study area is irrelevant to the monsoon season.

In this study, PCA was applied to four parameters to identify the most discriminated parameter as well as to understand the major potential source that are contributing to the flood occurrence in $\mathrm{Sg}$. Golok. Only strong factor loadings were selected for PCs construed [21].

From the analysis, the F1 (1.339) and F2 (1.081) were obtained as the eigenvalue more than one $(>1)$. It was further justified by their variability $33.484 \%$ and $27.034 \%$ respectively. Table 2 summarized the result of the analysis.

Table 2: Eigenvalues for Factors from PCA

\begin{tabular}{|c|c|c|c|c|}
\hline & F1 & F2 & F3 & F4 \\
\hline Eigenvalue & 1.339 & 1.081 & 0.955 & 0.625 \\
\hline Variability (\%) & 33.484 & 27.034 & 23.863 & 15.619 \\
\hline Cumulative \% & 33.484 & 60.518 & 84.381 & 100.00 \\
\hline
\end{tabular}

The result showed in Table 3 and Fig. 1, VF1 comprised strong significant factor loading towards stream flow and suspended solid with value of 0.812 and 0.764 respectively. On the other hand,
VF2 with eigenvalue 1.081 and variance of $27.034 \%$ showed positive moderate factor loading towards rainfall $(0.714)$ and water level (0.650).

From the result, PCA came out with strong factor loading for stream flow. This situation occurred when there was certain volume of water flowing in the stream channel. However, the rate of stream flow influenced by factors either precipitation (rainfall) run-off in the watershed or the physical characteristic of the stream [22].

Table 3: Factor Loadings after Varimax Rotation

\begin{tabular}{|c|c|c|}
\hline & VF1 & VF2 \\
\hline Water Level & -0.204 & $\mathbf{0 . 6 5 0}$ \\
\hline Stream Flow & $\mathbf{0 . 8 1 2}$ & 0.239 \\
\hline Rainfall & 0.176 & $\mathbf{0 . 7 1 4}$ \\
\hline Suspended Solid & $\mathbf{0 . 7 6 4}$ & -0.339 \\
\hline \multicolumn{2}{|c|}{ Values in bold correspond for strong factor loadings }
\end{tabular}

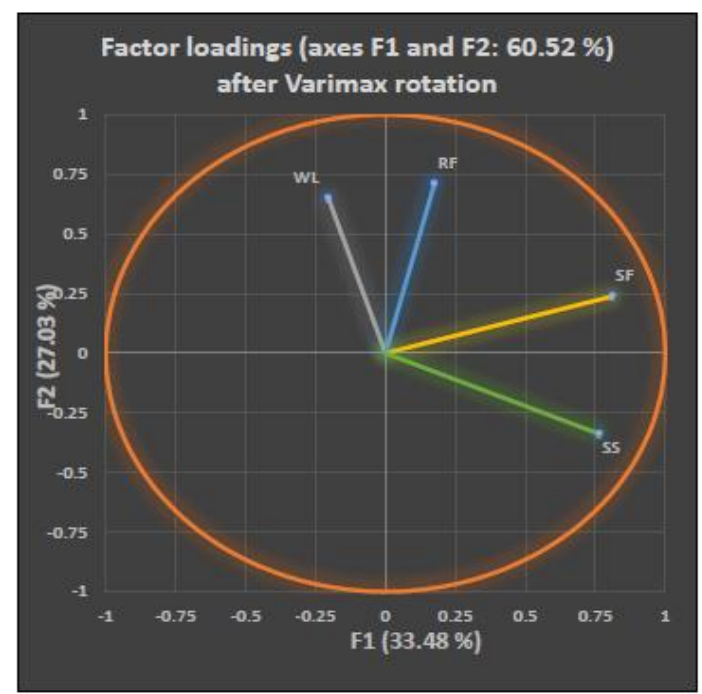

Fig. 1: Factor Loadings Plot after Varimax Rotation

In this study, the physical features of the stream in Sg. Golok were highlighted where depth, width and its channel shape were degraded. As the depth increase and small perimeter of width, the stream flow became rapid caused an overflow of water [23]. This because of shallow stream cannot bear to accommodate higher volume of water till it was enough to trigger flood occurrence.

When flood water rise, the slope of stream as it flows to the ocean and stream depth were the factor for the stream flow velocity became aggressive. As more water was added either through rainfall, tributary streams or from groundwater seeping into the river, the discharge and velocity increased the stream's competency and capacity resulting in flood $[24,25]$.

The increased rate of water flow could cause the suspended sediment yields which were related to the incidence of rainfall that which affected the increasing value of river discharge [26].

Following that, erosion phenomenon that caused by stream flow affected towards suspended solid. Hence, this variable also recorded to be one of the strong factor loadings in VF1.

There were a lot of precipitation or substance fell within the water body during heavy rainfall and the settlements affected changes in water level. Other than balanced system of water cycle, large amount of precipitation was the reason for the flood to happen, causing the river to overflow [22].

Besides, expansion and development by human activities can contribute to the high number of suspended solid found in the study area. Hence, as the development continually occurred, the pollutants especially non-point source pollutants were generated and transported through the catchment area [27]. These pollutants deposited at the waterways affected the changes in water level which eventually triggered the flood occurrence. Meanwhile in $\mathrm{VF} 2$, it showed that strong factor loading towards rainfall and 
water level in this study. Many previous studies proved that, this condition was affected by the northeast monsoon that happened on December until March. Moreover, Sg. Golok had been recorded to impose with the highest water level due to prolonged rainfall during 2014 that vulnerable to flood occurrence [6].

By received plentiful of heavy rainfall for every year, the water level in the area was affected by increased drastically. Ground became waterlogged with water remained on the surface caused the stream full and burst their banks. Gong et al. [28] stressed that it was important parameters in predicting the first "flush" based on event maximum rainfall intensity and the time of its appearance from the start of the event [28].

\subsection{Determination of Risk Factors Pattern of Selected Variable That Caused Flood Occurrence in the Study Area}

Fig. 2 showed the result for water level with mean of $13.58 \mathrm{~m}$ and dispersion $6.652 \mathrm{~m}$ showed that the Lower Control Limit (LCL) and Upper Control Limit (UCL) were $0.000 \mathrm{~m}$ and $3.776 \mathrm{~m}$, respectively.

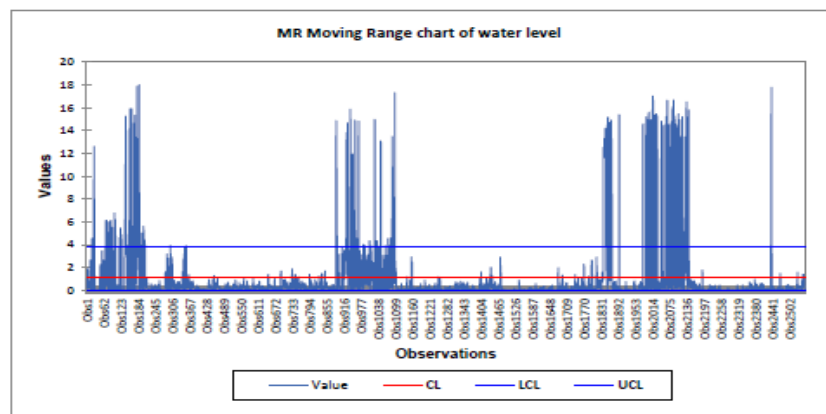

Fig. 2: SPC Graph Based on Water Level in the Study Area

Some of the reading had exceeded the UCL which it considered as high risk. For instance, the reading on several spikes shown in the figure happened in April 2010, Jun 2012, Jan 2014, March to October 2014 and Jun 2016. The results showed that the human activities in the study area affect the climate change in the study area Based on the higher peak value showed, it was obviously referred to human activities that affected the water storage as the stream was shallowed resulting in increasing of water level.

In addition, pattern in Fig. 3 portrayed the results of SPC using Control Chart for stream flow. With the mean value of $70.04 \mathrm{~m}^{3} / \mathrm{s}$, the Control Limit (CL) was $25.930 \mathrm{~m}^{3} / \mathrm{s}$ between the LCL and UCL of $0.000 \mathrm{~m}^{3} / \mathrm{s}$ and $84.736 \mathrm{~m}^{3} / \mathrm{s}$ respectively.

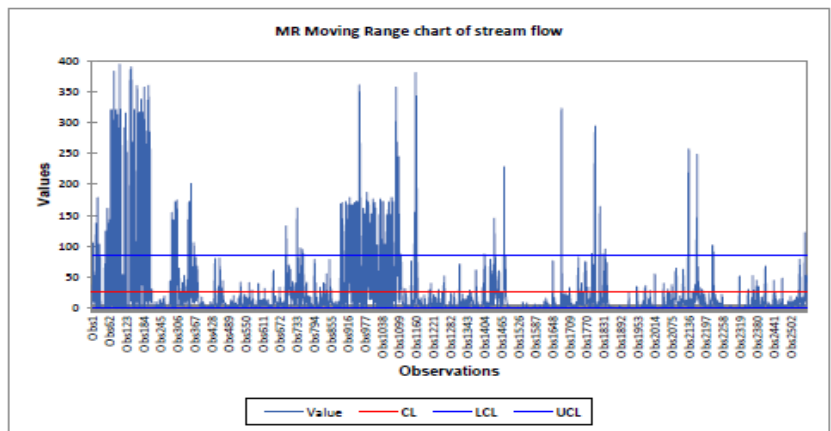

Fig. 3: SPC Graph Based on Stream Flow in the Study Area

The findings explained that, destruction along the stream bank can occur if the value is beyond the UCL. From the result, most of the spikes throughout the years obviously showed high value of stream flow in the study area which resulting from the changes of stream characteristics and precipitation run-off along the stream.

Fig. 4 presented the results of SPC for rainfall in the study area. The CL of the rainfall was recorded for $10.895 \mathrm{~mm}$ with UCL of
$35.602 \mathrm{~mm}$. The highest peak in the graph exhibited that highest value of the study area received rainfall on the end year 2014 until the beginning year 2015 .

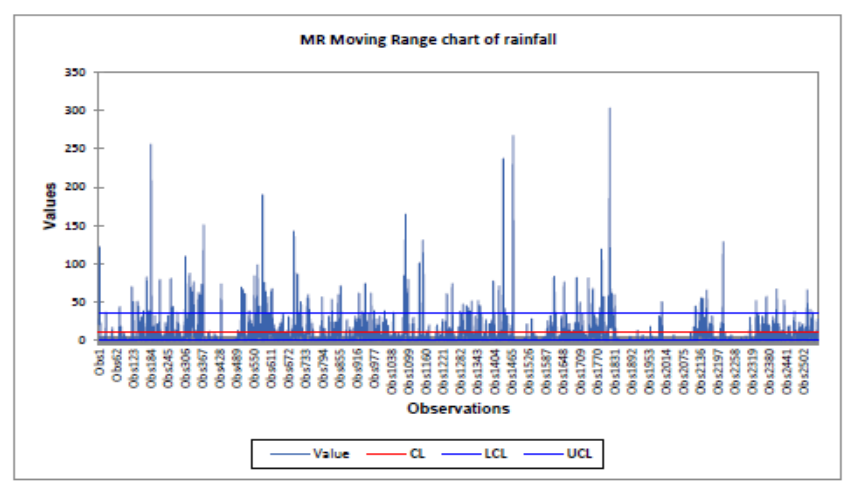

Fig. 4: SPC Graph Based on Rainfall in the Study Area

Referring to Fig. 5, the mean value for suspended solid was $398.50 \mathrm{mg} / 100$ with the dispersion of $973.72 \mathrm{mg} / 100$. The LCL and UCL of the suspended solid in this study area were recorded for $0.000 \mathrm{mg} / 100$ and $930.658 \mathrm{mg} / 100$, respectively with the CL of $284.792 \mathrm{mg} / 100$

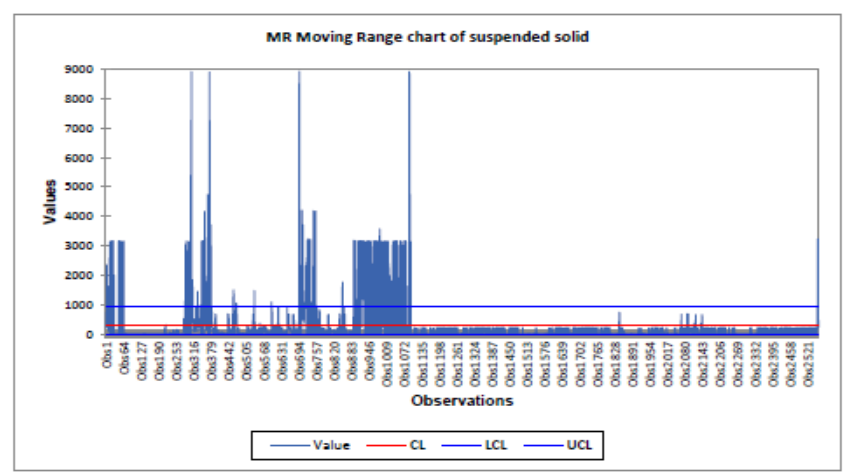

Fig. 5: SPC Graph Based on Suspended Solid in the Study Area

Based on the graph, it showed that human development was the main contribution to the high value of suspended solid in the study area. Hence, if the value of suspended solid in the study area exceeds the UCL, the risk for flood to occur would be higher. Thus, the discharge of suspended solid must ensure within the CL. This is not only for flood preventing but also in reducing the environmental pollution in the study area.

\section{Conclusion}

The relationship between variables of water level and suspended solid in this study are proven to be strong and significant. Strong corresponds of suspended solid change the rate of water level. Thus, it is appropriate for the local authorities to implement the restriction of development, land use zoning and resettlement of population to reduce the impact of flood towards the study area that become worsen year by year.

Additionally, the flood risk pattern in Sg. Golok majorly caused by monsoon season. That was identified by the strong factor loading where it was indicated towards rainfall and water level. Therefore, to improve the flood risk pattern in the study area, the river bank of the Sg. Golok should be further developed with proposed flood mitigation and safety zones as well as enforcement of new regulation under Disaster Management Act 2005. This would be proactive actions by the government, and the results can be seen with the improvement of flood risk pattern in the study area.

For the determination of risk factors pattern of selected variable, it was specified that most of the variables had exceeded the upper control limit. It's considered as high risk where it is enough to 
trigger flood occurrence. Human development was main contribution to the high value especially in suspended solid. It is not deniable that monsoon season is the contribution of flood to occur too. These variables affected the changes of water level resulting in above the upper control limit.

\section{Acknowledgement}

I would like to express my gratitude to my Supervisor, Dr. Ahmad Shakir Mohd Saudi for his immense knowledge, insightful comments and hard ideas. Highly thank my fellow friends under a mutual supervisor for stimulating discussions and enlightening me about this research and, to UNIKL for golden opportunity in completing this wonderful project within the limited time.

\section{References}

[1] Department of Irrigation and Drainage (DID), (2017), DID, http://www.water.gov.my, last visit:15.11.2017

[2] Shafiai S \& Sukeri M, "Flood Disaster Management in Malaysia A Review of Issues of Flood Disaster Relief during and PostDisaster", The European Proceeding of Social \& Behavioural Sciences, (2016), pp: 164-170.

[3] Malaysian Meteorology Department (MMD), Monsoon Season in Malaysia,

(2017) http://www.met.gov.my/in/web/metmalaysia/home

[4] Baharuddin KA, Wahab SFA, Rahman NHNA, Mohamad NAN, Kamauzaman THT, Yazid MNA \& Majid MRA, "The RecordSetting Flood of 2014 in Kelantan: Challenges and Recommendations from an Emergency Medicine Perspective and Why the Medical Campus Stood Dry", Malaysian Journal of Medical Sciences, 22(2), (2015), pp: 1-7.

[5] Gasim MB, Jamil M, Rahim SA, \& Toriman ME, "Water-Quality Assessment of the Langat River at Kilometre 7, Jalan Kajang-Bangi, Selangor, Malaysia", The Arab World Geographer, 12(3-4), (2009), pp: $188-198$

[6] Hussin WNTW, Zakaria NH \& Ahmad MN, "Knowledge Sharing and Lesson Learned From Flood Disaster: A Case in Kelantan", Journal of Information Systems Research and Innovation, 9(2), (2015), pp: 1-10.

[7] Wee TS \& Ariffin R, Fakulti Pengurusan Teknologi, Perniagaan dan Keusahawanan, Persidangan Kebangsaan Geografi Dan Alam Sekitar, (i), (2011), pp: 1-20.

[8] Hashim M, Reba MNM, Misbari S, Pour AB, Jaw SW, Lah NZA, Khairul M \& Halim MKA, "Satellite-Based Inventorying Major Landslides in Kelantan River Basin due to Massive December 2014 Flood Episode", (2015), pp: 1-5.

[9] Glur L, Wirth SB \& Bu U, "Coincide with Cooler Periods of the Past 2500 Years", (2013), pp: 1-5,

[10] Doocy S, Daniels A, Murray S \& Kirsch TD, "The Human Impact: a Historical Review of Events and Systematic Literature Review", PLOS Currents Disasters, Vol.1, (2013), pp: 1-32.

[11] Akasah ZA \& Doraisamy SV, "2014 Malaysia Flood: Impacts \& Factors Contributing Towards the Restoration of Damages", Journal of Scientific Research and Development 2, 2(14), (2015), pp: 53-59.

[12] Toriman ME, Pereira JJ, Gasim MB, Sharifah Mastura SA, \& Aziz NAA, "Issues of climate change and water resources in peninsular Malaysia: The case of north Kedah", The Arab World Geographer, 12(1-2), (2009), pp: 87-94.

[13] Ran J \& Nedovic-Budic Z, "Integrating Spatial Planning and Flood Risk Management: A New Conceptual Framework for the Spatially Integrated Policy Infrastructure", Computers, Environment and Urban Systems, 57, (2016), pp: 68-79.

[14] Jaafar AS, Sidek, LM, Basri H, Zahari NM, Milad J, Ros FC \& Roseli, ZA, "A Review on Flood Events for Kelantan River Watershed in Malaysia for Last Decade (2001-2010)", IOP Conference Series Earth and Environmental Science, 32(1), (2016).

[15] Chong WC, "Managing Flood Problems", Buletin Ingenieur, (2016), pp: $38-43$.

[16] Saudi ASM, Juahir H, Azid A, Toriman ME, Kamarudin MKA Saudi MM, Mustafa AD \& Amran MA, "Flood Risk Pattern Recognition by Using Environmetric Technique: A Case Study in Langat River Basin”, Jurnal Teknologi, 77(1), (2015), pp:145-152.
[17] Brough KE, "Studies of Brisbane Municipal Water Quality Using Inductively Coupled Plasma - Mass Spectrometry and Chemometrics", Masters by Research Thesis, Queensland University of Technology, (2015)

[18] Shafii NZ, Saudi ASM, Mahmud M \& Rizman ZI, "Spatial Assessment on Ambient Air Quality Status: A Case Study in Klang, Selangor, Journal of Fundamental and Applied Sciences, Vol.9, No.4S, (2017), pp: 964-977.

[19] Trubin IA, "Exception Based Modeling and Forecasting", $34^{\text {th }}$ International Computer Measurement Group Conference, December 7-12, 2008, (2014)

[20] Engmann S, "Quantitative Methods Inquires Compating Distributions: The Two Sample Anderson-Darling Test as an Alternative to the Kolmogorov-Smirnoff Test”, (2011), pp: 1-17.

[21] Nasir MFM, Zali MA, Juahir H, Hussain H, Zain SM \& Ramli N, "Application of Receptor Models on Water Quality Data in Source Apportionment in Kuantan River Basin", Iranian Journal Environmental Health Science \& Engineering, 9(1), (2012), pp:18.

[22] Simmadoraiappanna S, "Hydrological Study and Estimating Flow Rate of Sg Lebir, Kuala Krai, Kelantan", Research Thesis, Faculty of Civil Engineering and Erath Resources, Universiti Malaysia Pahang, (2016).

[23] Nelson SA, "River Systems \& Causes of Flooding", Natural Disasters, Tulane University, (2016), pp: 1-12.

[24] Andreas V. Bibliography Background about KRIS Stream Flow, (December 1964), (2011), pp: 1-4.

[25] Hussin MH, "Flood Estimation and River Analysis of Sg. Isap, Kuantan", Undergraduates Project Papers, Universiti Malaysia Pahang, $\quad$ (2010), http://iportal.ump.edu.my/lib/item?id=chamo:52639\&theme=UMP 2

[26] Wahab NA, Kamarudin MKA, Gasim MB, Umar R, Ata FM, \& Sulaiman NH, "Assessment of total suspended sediment and bed sediment grains in upstream areas of Lata Berangin, nu", International Journal on Advanced Science, Engineering and Information Technology, 6(5), (2016), 757-763.

[27] Baharudin F, "A Study on Rainfall-Runoff Characteristics of Urban Catchment of Sungai Kerayong", Master of Science Thesis, Universiti Sains Malaysia, (2007).

[28] Gong Y, Liang X, Li X, Li J, Fang X \& Song R, "Influence of Rainfall Characteristics on Total Suspended Solids in Urban Runoff : A Case Study in Beijing, China", Water, 8(7), (2016), pp:278. 